Ewa Pańkowska

DOI $10.15290 / \mathrm{sw} .2020 .20 .06$

Uniwersytet w Białymstoku

Wydział Filologiczny

Katedra Badań Filologicznych „Wschód - Zachód”

tel.: +48 573-126-073

e-mail: e.pankowska@uwb.edu.pl

ORCID ID: https://orcid.org/0000-0002-3820-8224

\title{
В «мрачном» и «таинственном» мире произведений Михаила Елизарова (безумие и «черная магия» в повести Ногтu)
}

Ключевые слова: Михаил Елизаров, анормальность, безумие, мистический, магический

Михаила Юрьевича Елизарова (род. 1973), несомненно, можно отнести к числу самых неординарных личностей среди современных русских (точнее, русско-украинских) писателей ${ }^{1}$. Необходимо также отметить, что Елизаров одновременно и автор-исполнитель. В 2010 году

1 Елизаров родился на западе Украины, в Ивано-Франковске, учился на юго-востоке Украины, с 2008 года переехал жить в Москву: «И хотя его так много связывает с Украиной, он считает себя русским писателем» [Дементьева 2014, online]. На вопрос, почему он уехал с Украины, Елизаров отвечает: «Там гнусно. Я вырос в советской Украине. Мое детство прошло в коммунальной квартире, но от него осталось очень светлое ощущение. Это было в Ивано-Франковске. (...) Потом мы переехали в Харьков, я поступил в университет, угодил в армию, все было ничего. И вдруг появляется плесень, которая начинает пожирать все мое прошлое. Эта чудовищная муть говорит на украинском языке. Я не против украинского, но он начал пожирать русский. С моей точки зрения, юг, юго-восток Украины и Харьков являются русскими землями. Пусть Западная Украина создает свое государство и живет самостоятельно. Но сегодня в Харькове, на востоке Украины торжествует местечковый западно-украинский менталитет. Он очень тяжелый и агрессивный. Он нетолерантен, он не оставляет места моей русской культуре. Я принимал украинскую культуру, я ее любил, теперь я не могу ее любить. Закрыты русские кафедры в Харьковском университете. Ставятся памятники фашистским подонкам. (...) Как мне жить в этом городе?» [Шаповал 2008, online]. 
он создал собственный музыкальный проект, который назвал «бардпанк-шансоном»². Как констатирует сам прозаик-музыкант:

(...) Они чередуются - проза, музыка [Беседин 2012, online]. (...) В прозе порою невозможно высказать то, что легко получается в песнях. (...) большая форма (проза - Е.Р.) предполагает компромиссы, нюансы. А песни бескомпромиссны, и в них я бываю более смелым. Песня удобна - маленькое компактное произведение, концентрат идеи [Смирнов 2012, online].

Песни Елизарова «сильны как молот и остры как серп», и поэтому они могут шокировать слушателей, прежде всего обильным количеством нецензурной лексики (своей грубостью и черным юмором), но также затрагиваемой в них спорной тематикой, о чем свидетельствуют уже сами названия елизаровских композиций, как например песня Сталинский костюм со словами: «Откровенно не хватает людям Сталина» [Дроздова 2017, online]. Здесь уместно процитировать мнение Павла Басинского, писателя, литературоведа и литературного критика: «Елизаров подчеркнуто парадоксален и агрессивно провокативен» [Басинский 2012, online]. Можно сказать, что эти замечания Басинского в равной степени касаются и музыкальных, и литературных произведений Елизарова. Елизаровская «провокация», часто в виде своеобразного «насилия» над тем, что люди ценят и уважают (это, например, преданность, искренность в отношениях, любовь), для одних кажется чем-то заманчивым, для других, наоборот, чем-то отталкивающим ${ }^{3}$. В связи с этим жесткую, радикальную, мрачную прозу Елизарова воспринимают и оценивают очень по-разному: «(...) Некоторые критики называют его произведения "скандально-эпатажным тошнотворным трэшем (от англ. мусор, хлам - Е.Р.)", другие - "интеллектуально-насыщенной беллетристикой” » [Mархинина 2013, online]; од-

2 Как объясняет сам автор: «"Бард-панк-шансон” - условное название, скорее ирония над потребностью журналистов как-то обозвать, классифицировать всякое художественное направление, жанр. У меня воинские песни. Песни вообще должны быть воинскими» [Захарова 2016, online].

3 В текстах Елизарова много агрессии, жестокости, неконтролируемой ярости, много сцен насилия, наблюдается также своего рода пристрастие прозаика к подробному описанию «мертвого», то есть тяготение к некроэстетике [Безрукавая 2014, 100]. Все это может настораживать, поражать, пугать, даже ужасать, а в конечном итоге и отталкивать неподготовленного читателя. В повести Госпиталь (2001), например, изображена настоящая «оргия» жестокости, безумия, апокалиптичности, главным действующим лицом которой является Прищепин, «дед»-садист. Елизаров затрагивает в этом произведении тему «дедовщины», а также распада Советского Союза (см. подробнее Меркушов С.Ф., 2013, Об абстракииях и аллегориях в повести M. Елизарова «Госпиталь», «Вестник ТвГУ» вып. 1, с. 264-270). 
ни считают тексты Елизарова «новым, ярким, сочным словом в литературе», другие же «ругают за натурализм, депрессивность и показ мерзостей жизни» [Сафрошина 2012, online]. Именно такая неоднозначность и противоречивость оценки сопутствовала роману Библиотекарь (2007), за который Елизаров удостоился литературной премии «Русский Букер» в 2008 году. Присуждение этой «лучшей», «самой престижной», «элитарной» (при этом консервативной) премии уроженцу Ивано-Франковска (что также подчеркивалось противниками Елизарова) вызвало бурную реакцию критики, и отзывы, соответственно, были диаметрально противоположными, они варьировались в диапазоне от бурных восторгов до обвинений в пошлости, в фашизме и чуть ли не проклятий [Дайс 2012, online]. Горячо обсуждали, конечно, сам роман, по мнению многих, весь пропитанный ностальгией по Совет-

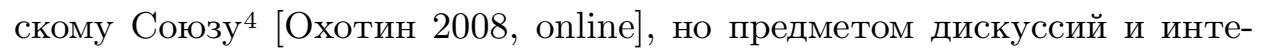
реса стал также довольно «экстравагантный», «брутальный» внешний вид Елизарова, так как вместо благонадежного автора в костюме при галстуке на церемонии награждения появился рослый мужчина с длинными волосами, в чёрной одежде в стиле милитари. Получение «Русского Букера» сам лауреат снабдил следующим комментарием: «Предположим, что "Букер" - это живой организм. Премия претерпевает трансформацию, приходит другая элита. Или меняются представления о писателе, получающем Букер. И одет он - не в костюм с бабочкой, а в штаны "милитари" и высокие шнурованные ботинки» [Смирнов 2008, online].

По словам Дмитрия Бавильского, писателя, литературоведа и критика: «У Михаила Елизарова странная репутация странного человека, которую (...) не способны поколебать никакие литературные пре-

4 Можно сказать, что герои романа ностальгируют по идеалу - по «Союзу Небесному». Как добавляет сам Елизаров: «Жаль замечательной идеи, лучше которой человечество ничего не придумало: всеобщее равенство, социальная защищенность, право каждого на образование и труд. Жаль попытки построить коммунистическое общество. Да, мне многие вещи не нравились в советской системе. Я не приветствую методы, которыми Сталин решал проблемы. Но если бы меня поставили перед выбором, быть за царскую Россию или за Россию красную, я был бы на стороне красных» [Караев 2011, online]. В Библиотекаре автор повествует о борьбе (жестокой и кровавой) неких группировок за право обладания забытыми книгами покойного писателя-соцреалиста Дмитрия Громова. Оказывается, что в этих текстах скрыт тайный смысл, доступный лишь немногим посвященным [Токарев 2008, online]. Книги Громова обладают необъяснимой силой - преображают сознание читателя, а свое действие они могут оказать лишь при соблюдении двух условий - только непрерывное и внимательное чтение «погружает человека в в особое психоделическое состояние - грусти, терпения, силы, ярости или светлой памяти о том, чего никогда не было» [Захарова 2016, online]. 
мии ${ }^{5} \gg$ [Бавильский 2010, online]. Ссылаясь именно на такую точку зрения, можно рискнуть и констатировать, что в центре внимания автора Библиотекаря оказываются всякого рода странности, аномалии, социальные патологии, ущербные личности (в том числе люди с психическими расстройствами, но и «уроды» с врожденными физическими дефектами), иными словами, прозаика как будто прежде всего интересует анормальность в широком смысле, анормальность как отклонение от нормы, отклонение от общепринятого и закономерного ${ }^{6}$. Кажется, что Елизаров намеренно обнажает темные стороны человеческой натуры и сосредоточивается на внутреннем разладе во взаимоотношениях между людьми (между близкими людьми), на душевном разладе, который нередко прикрывается внешним, конечно, мнимым приличием. Можно предполагать, что таким образом писатель пытается подчеркнуть нынешний «дефицит духа», показывает при этом беспомощного и беззащитного, на самом деле, человека, который не в состоянии бороться против главных грехов нашего времени, безнравственности ${ }^{7}$ и жестокости ${ }^{8}$ (физической, словесной, эмоциональной), и который поэтому неизбежно попадает в ловушку лицемерия, обмана, самообмана и очень опасной моральной вседозволенности ${ }^{9}$. Хорошим и ярким примером может здесь послужить ситуация изображена Елизаровым

5 Елизаров - финалист премии «Национальный бестселлер» (в 2011 году за роман Мультики), а также победитель премии «НОС» в 2014 году в номинации «Приз зрительских симпатий» с книгой $\mathrm{Mbl}$ выщли покурить на 17 лет....

6 Анормальность - аномалия, аномальность, болезненность, дефективность, извращение, извращенность, неадекватность, неестественность, ненормальность, неполноценность, неправильность, несоответствие, отклонение, отклонение от нормы, патология, противоестественность, уродливость.

7 Сам Елизаров утверждает: «(...) Люди должны быть свободны, их не должно ограничивать ничто, кроме нравственного закона» [Караев 2011, online].

8 В одном из своих интервью прозаик подчеркивает, что современный мир «ужасно жесток (...). Он куда более жесток, чем в XX веке». Писатель добавляет при этом: «По-моему, это новый, еще более страшный этап исторической жестокости: абсолютное равнодушие к людям» [Михаил Елизаров - Портреты 2010, online].

9 Но это действительно только одно из возможных предположений, а тем самым лишь один из возможных вариантов интерпретации елизаровских произведений, в которых присутстует оттенок мистической неуловимости. В связи с этим сложно однозначно и точно определить, с какой целью писатель сосредоточивает свое внимание именно на различных формах проявления анормальности. Итак, может быть, что он просто фиксирует все эти «уродливые» явления или же намеренно эпатирует читателя изобилием всякого рода «патологий», и здесь появляется существенный вопрос, почему прозаик пытается шокировать читающую публику: это лишь художественный прием, который он охотно использует, или Елизаров все-таки старается клеймить «аномалии», а тогда можно констатировать, что в его текстах намечается и своеобразное дидактическое начало. 
в рассказе Допрос (дебютный сборник Ногти, 2001). Итак, муж «допрашивает» свою жену. Можно догадаться, что он это делает регулярно и довольно часто, и каждый раз заставляет свою супругу сознаться в измене, упорно при этом добивается того, чтобы она подробно рассказала о самых извращенных деталях очередного физического сближения с другим мужчиной. Жена постепенно во всем признается:

В ночь свадьбы я фальсифицировала девственность краской. Мужу начала изменять с первых дней. Все случаи, когда я запаздывала открывать двери на звонок мужа, означают мою измену. Я сожительствовала с мужчинами дома и на работе. (...) Во всех моих преступлениях перед мужем я чистосердечно признаюсь и раскаиваюсь. В дальнейшем обещаю этого не делать (не изменять), в чем подписываюсь... [Елизаров 2011, 214, 215].

Финал этой истории оказывается одновременно и банальным, и неожиданным: есть раскаяние и есть прощение «- Чистосердечное признание сдала! - Чистосердечное признание принял!» [Елизаров 2011, 215]. Открытым остается только вопрос, почему женщина все это делает: «она действительно постоянно изменяет мужу?» или «она устала от «допросов» и ради собственного спокойствия говорит именно то, что ее муж хочет услышать?». А муж как будто «кормится» этими «откровенными признаниями», утверждаясь в своем убеждении, что он стоит на страже нравственности, что он благородный человек, так как всегда принимает «чистосердечное» признание жены и терпеливо ждет, когда супруга наконец-то «очистится», и они вернутся к полноценным взаимоотношениям. Возникает здесь очередной вопрос, кто из супругов на самом деле является настоящим лицемером. То, что происходит между мужем и женой, можно воспринимать как полную деградацию отношений между супругами или же интерпретировать как изысканную «любовную игру», которую близкие люди ведут для того, чтобы избежать пресыщения друг другом. Елизаров пытается показать, как анормальность постепенно становится нормой общения, поведения так называемых «нормальных» и «порядочных» людей. Писатель затрагивает «неудобные темы» (часто аморальные с общепринятой точки зрения): это, например, извращенные семейные отношения, патологическая зависимость мужа от жены, действия, направленные на подчинение и подавление другой личности, недопустимая близость между отцом и дочерью (телесная, половая, но и эмоциональная, душевная близость), социальная стигматизация и психически больных людей, и людей с физическими недостатками. Можно сделать вывод, что выбирая именно спорные темы, вызывающие сильные, тре- 
вожные эмоции, а иногда даже действующие угнетающе, Елизаров хочет побудить читающую публику мыслить, в чем, кстати, он и сам убеждает:

Я категорический противник того, чтобы развлекать. Воспитывать тоже не моя задача. Я не пытаюсь манипулировать сознанием читателя, чтобы подтолкнуть его к чему-то, чтобы он сделал что-то определённое или кого-то осудил. (...) Я просто даю некую картинку, а дальше человек сам решает, что с этим материалом делать. (...) Если я сумел каким-то образом завоевать ваше внимание, подтолкнуть к работе мысли... ну, я очень рад [Мархинина 2013, online].

В одном из своих интервью Елизаров заявил: «(...) я скорее анархист. Не люблю государство, которое ломает человека» [Караев 2011, online]. Можно констатировать, что подобного рода «анархизм-индивидуализм», желание быть свободным от всевозможных принуждений и ассоциаций, попыток причисления к каким-то группировкам и направлениям свойственны не только Елизарову-гражданину, у которого есть определенные политические и общественные взгляды ${ }^{10}$, но и Елизарову-писателю, который объясняет: «Думаю, что в литературе я сам по себе. По крайней мере, я не чувствую никакого близкого соседства» [Прилепин 2015, online] ${ }^{11}$. Конечно, попытки определить точное «месторасположение» Елизарова в литературном пространстве и каким-то образом классифицировать его творчество предпринимались и предпринимаются исследователями литературы. Итак, например, с одной стороны, автора Ногтей называют «новым Гоголем»12, с другой - лишь эпигоном Владимира Сорокина ${ }^{13}$, одни причисляют Елизарова к постмодернистам, другие - к «новым реалистам» «нулевых», а при характеристике его произведений употребляют термины: «альтернативный постмодернизм», «гротескующий символизм», «игровой реализм», «субъективный реализм», «радикальный реализм»,

10 Уместно здесь процитировать слова прозаика: «(..) Все равно любая государственная проекция направлена на порабощение человека. Ни одному мороку я не симпатизирую» [Павлов 2018, online].

11 Елизаров подчеркивает: «Я сторонюсь коллективов, систем и иерархий» [Павлов 2018, online].

12 «Проза Михаила Юрьевича Елизарова (...) продолжает мистико-абсурдистскую линию русской литературы, представленную творчеством Н. В. Гоголя (..) и др.» [Имихелова, Колмакова 2016, 168].

13 См., например: Юрьев Д.Ю., 2016, Твориеская личность М. Елизарова: аспекть критической рефлексии и самоидентификации, «Научный журнал КубГАУ» № 120 (06), [online], http://ej.kubagro.ru/2016/06/pdf/07.pdf, [08.02.2020]. 
«грязный реализм», «патологический реализм», но также «мистический реализм», «магический реализм»14. В таком контексте правильным кажется утверждение, что Елизаров предлагает читателю довольно «взрывную» смесь постмодернистских ${ }^{15}$ («игровых») и реалистических (с натуралистическими зарисовками) приемов, «позволяющих емко и пластично визуализировать образы русской действительности ${ }^{16}$, осмысливать ее насущные проблемы» [Юрьев 2016, online], но и искусно, гармонично вплетать в эту действительность «магическое начало» ${ }^{17}$, присутствие которого значительно расширяет границы обыденного пространства. Прозаик как будто подсказывает: «у всего есть мистическая подоплека и второе дно». В произведениях Елизарова фантастическое плавно сплетается с реальным, обыденное соединяется со сверхъестественным, что в итоге оставляет возможность двойного толкования, двойной мотивировки - некоторые происходящие события (эти «мистические» происшествия) могут получать как реальное (эмпирически или психологически правдоподобное), так и ирреальное объяснение ${ }^{18}$. Следует при этом напомнить и подчеркнуть, что одной из характерных для магического реализма (как художественного явления в искусстве XX в.) черт является именно сосуществование и взаимопро-

14 См. подробнее Pańkowska E., 2018, Михаил Елизаров: между постмодернизмом и «магическим реализмом» (Ногти, Библиотекарь, Мультики), "Acta Neophilologiса" т. XX, № 1, с. 205-207.

15 Здесь особого внимания заслуживает «интертекстуальная ткань» елизаровских произведений (учитывая факт, что интертекстуальность считается основной чертой постмодернистской литературы).

16 В текстах Елизарова конкретность (то есть социально-исторические «идентификаторы эпохи», указывающие на определенные реальные события, а также элементы автобиографизма) сочетается с условностью (иногда некой сказочной условностью), метафоричностью, параллельно используются формы абсурда, гротеска [Колмакова 2015, 223-224].

17 Автор Библиотекаря объясняет: «Все эти элементы, мистические или сказочные, использую как некие ферменты, облегчающие пищеварение. У меня есть идея, которую я собираюсь сообщить, и, если ее представить в чистом, голом виде, она может показаться неинтересной и быть отторгнутой. Если же идею упаковать в некую оболочку (сказочно-мистическое - достаточно сладковатая субстанция), она позволяет проглотить идею в виде экшена, но внутри останется зародыш идеи. Это зачастую просто вспомогательный инструмент» [Бурмистрова 2008, online].

18 Наглядным примером может здесь послужить роман Мультики (2010): однажды главный герой, Герман Рымбаев, «трудный подросток», в качестве наказания попадает в Детскую комнату милиции, но не в обычную, а в очень странную, «волшебную» комнату, и там он подвергается «специальным» воспитательным процедурам. Все то, что происходит с Рымбаевым, можно считать плодом его больного воображения (игрой подсознания) или, как замечает сам автор Мультиков: «(...) Это переживания лирического героя, в жизнь которого вторглось необычное, необъяснимое» [Мархинина 2013, online]. 
никновение первичной и скрытой реальностей, переплетение фантастического и обыденного: «Стремясь в целом сохранить верность принципу жизнеподобия, писатели магического реализма вместе с тем активно вводят в повествование мотив чудесного» [Кислицын 2011, 275-276].

Подытоживая, можно констатировать, что проза Елизарова содержит в себе нечто загадочное и необъяснимое, темное и потустороннее (даже «инфернальное»), но одновременно она органично вписывается в реалии русской действительности, поэтому мы имеем дело с «магией» (временами - «черной магией»), умело вмонтированной в повседневный реализм. Роман Богословский, журналист, прозаик и публицист, стиль Елизарова называет «магическим реализмом, возросшим на советско-российской почве» [Богословский 2019, online].

В связи с вышеизложенным мы считаем уместным в настоящей статье сосредоточить внимание на повести Ногти (2001), опубликованной в составе одноименного сборника Елизарова, так как в этом произведении мы найдем, во-первых, синтез реального и сверхреального, а во-вторых, обнаружим интересную трактовку сложной, широкой и многоплановой темы: «анормальность», которая в этом случае охватывает: и безумие, и ущербность, неполноценность (в плане физическом и интеллектуальном), и странность как отклонение от «нормального», но одновременно и достойное порицания непринятие «нормальными» людьми этой странности. Повесть Ногти условно можно назвать «метафизической сказкой» (по мнению некоторых, «макабрической сказкой») или же «притчей в готическом стиле», главными героями которой являются горбун Александр Глостер и некрасивый молчун Сергей Бахатов, выпускники интерната для умственно отсталых детей, существа, отвергнутые и родителями, и обществом, лишенные заботы, любви и уважения, зато обреченные на постоянное унижение, одиночество, страдания, разного рода издевательства, существа, вызывающие у других лишь презрение, отвращение и страх: «Учителя, которые приходили из поселка, побаивались нас. Их отвращали наши лица, неправильные туловища, невнятные голоса, мимика, жесты - все вызывало брезгливый страх» [Елизаров 2011, 14]. Можно предполагать, что мальчиков поместили в интернат для слабоумных детей не столько за их умственную неразвитость ${ }^{19}$, сколько за их физическую

19 Конечно, нельзя исключить и тот факт, что герои все-таки страдали умственной отсталостью легкой (или умеренной) степени, но одновременно никто особо не пытался и не собирался развивать их интеллектуальный потенциал: «Но мы смогли научиться читать и писать, у меня иногда появлялись трудности с арифметикой, у Бахатова с гуманитарными дисциплинами, однако я подчеркиваю: мы были 
дефектность 20 (просто за их «другость»), которая в итоге послужила поводом и решающим фактором для того, чтобы Глостера и Бахатова называть и считать «дураками»:

(...) Бахатов с младенчества умел произвести тягостное впечатление о состоянии своего интеллекта - виной тому мятой формы череп и бесконечные слюни. (...) Я появился на свет горбуном - плод эгоизма и безответственности, резюме пьяных рук, постфактум отравленного вестибулярного аппарата. Меня не отдали к сколиозникам, а оставили на потеху у слабоумных. (...) Бахатов, в сущности, тоже был нормальным, только не красивым, и оставалось догадываться, что глотала или пила мамаша Бахатова, чтоб избавиться от него [Елизаров 2011, 7, 8].

В художественном мире елизаровской повести наступает своего рода смещение, а даже снятие границ между странностью, ненормальностью и уникальностью, исключительностью, так как оба мальчика, с точки зрения большинства, просто уродливые и недалекие воспитанники школы для сумасшедших, на самом деле обладают незаурядными способностями: Глостер отличается огромной («фантастической») физической силой ${ }^{21}$ и феноменальной музыкальной одаренностью, а Бахатов, в свою очередь, способен предсказывать и даже в какой-то степени «"корректировать" их общую, одну на двоих, судьбу» [Имихелова,

нормальными» [Елизаров 2011, 8]. Здесь необходимо учитывать, что повествование ведется от имени Глостера, поэтому все замечания, касающиеся поведения его самого, как и его друга, Бахатова, являются сугубо субъективными, что, впрочем, вполне естественно. Надо также помнить, что ущербные и ненормальные с точки зрения большинства люди (то есть люди, имеющие какие-либо проблемы с процессом нормального функционирования их психики) живут в своей собственной вселенной, которая кардинальным образом отличается от вселенной психически здоровых лиц [Tarnowska 2013, online].

20 Можно констатировать, что в повести Ногти Елизаров изображает стереотипное восприятие окружающими людей с врожденными физическими аномалиями. Как правило, именно такое критическое, неблагоприятное восприятие обусловлено внутренним страхом здоровых (в широком смысле этого слова) членов общества перед ущербностью, инаковостью и отличием. Ведь с давних времен «уродам и чудовищам» (то есть людям с физическими недостатками тела) придавали демонический характер, например: «(..) издревле считалось, что от хромого и горбатого следует ждать несчастья» [Глоба, online].

21 «У разных народов существуют поверья, связанные с физическими уродствами. (...) В любом врожденном горбуне есть огромная стихийная сила - причем не только чисто физическая - сила, с которой он не знает, что ему делать. И она передается дальше по наследству, производя на свет смутьянов, бунтарей и подрывников, одержимых стихийными духами. Поэтому в древности горбунам запрещалось иметь детей. Одержимость демонами любого горбатого человека неоднократно подчеркнута во многих древних текстах» [Глоба, online]. 
Колмакова 2016, 175]. Таким образом, уже с раннего детства между героями образуется очень сильная, можно даже сказать, что неразрывная и при этом мистическая связь ${ }^{22}$, которая как будто соединяет мальчиков в единое целое - их необычные способности дополняют друг друга, и благодаря этому тесному взаимодействию уникальных и неповторимых черт до определенного времени Глостер и Бахатов в состоянии выжить и существовать во враждебном для них мире - мире «нормальных» и «полноценных» ${ }^{23}$. Саша и Сережа могут рассчитывать лишь друг на друга, так как окружающие их люди под видом помощи пытаются просто использовать для своих целей этих наивных и совсем неприспособленных к самостоятельной жизни (к жизни вне стен интерната) молодых выпускников школы для слабоумных ${ }^{24}$. Чтобы «остаться в живых», герои начинают даже «общаться» и «сотрудничать» с инфернальными силами: «Почему бы и нет. (...) Для отверженных нет правил и принципов» [Богословский 2019, online]. Но за этот «договор с нечистью» Глостеру и Бахатову придется заплатить самую высокую цену.

Можно констатировать, что изображена в повести Ногти история жизни двух ущербных, но и необычных существ - это в сущности история существования между нормой и ее нарушением, между обычным и запредельным, между тем и иным миром, и оказывается, что: «Жизнь "этого" мира держится благодаря некоему ритуалу, позволяющему “заговорить" власть иного» [Дворцова 2011, online].

Итак, среди обыденности, но в кризисных и чрезвычайных ситуациях обладающий способностями шамана Бахатов с помощью собственных обгрызенных ногтей и клочков «Комсомольской правды» или какой-то другой газеты совершает некий «обряд спасения», специальный ритуал, ужасающий и одновременно комический, абсурдный и мистический. Во время проведения ритуала елизаровский колдун ${ }^{25}$ всту-

22 Бахатов выступает в роли наставника и «ангела-хранителя» Глостера.

23 Как замечает Саша: «Жизнь налаживалась» [Елизаров 2011, 47]. Герои стараются как-то встроиться в недружелюбный и опасный для них мир постсоветской реальности, со временем начинают даже использовать поставленный им диагноз «дурачка» в свою пользу: «(..) Нам совсем не хотелось полностью лишаться финансовой поддержки. Инвалидная пенсия, хоть и маленькая, могла кое-как прокормить, но, с другой стороны, перекрывала путь во многие сферы общества. После долгих раздумий мы нашли золотую середину. Бахатов решил остаться на инвалидности, для подстраховки. Я отважился идти в большую жизнь» [Елизаров 2011, 37].

24 Например, без зазрения совести можно втянуть Сашу и Сережу в преступное дело (грабеж магазинов), потому что они не понимают, что значит: «нарушить закон».

25 В художественном мире произведения можно заметить своего рода атрибуты вол- 
пает на территорию смерти и входит в непосредственный контакт с темными силами, которым он приносит в жертву свою кровь, а в конечном итоге отдает и свою жизнь [Имихелова, Колмакова 2016, 175].

Десять прозрачных полумесяцев Бахатов сплевывал на газету и, в зависимости от того, как легли ногти, делал выводы о будущем. Под влиянием ногтей информация, напечатанная в газете, трансформировалась в предсказание, Бахатов получал программу поведения на следующий месяц для себя и меня. Чистота соблюдения ритуала гарантировала нашу безопасность [Елизаров 2011, 11].

Эти «кровавые жертвоприношения» защищают Бахатова и Глостера от смертельного укуса «дьявольской» собаки и от погружения в бездну черного колодца (в бездну «нижнего мира»): «(...) Бахатов буквально истекал кровью, изорвав тело до ребер. С его слов я понял, что он этим откупил меня от колодца и собаки» [Елизаров 2011, 12]. Елизаров вводит в текст произведения извечный мотив борьбы добра со злом, борьбы сил Света и Тьмы ${ }^{26}$, тем самым в традиционно-реалистическое повествование прозаик вводит мистическую составляющую, которая значительно расширяет границы обычного восприятия окружающего нас мира. С одной стороны, писатель как будто пытается доказать, что лишь избранные, иные, маргинальные существа, именно такие, как Глостер и Бахатов, способны увидеть этот метафизический конфликт «светлого» и «темного», а с другой - «(...) авторская ирония придает мистическому событию («обряду спасения» - Е.Р.) характер амбивалентного, вследствие чего оно может быть мотивировано сумасшествием или временным помутнением рассудка героя» [Имихелова, Колмакова 2016, 175]. Таким образом и тема безумия, одна из сквозных тем в литературе, находит свое отражение в повести Ногтu ${ }^{27}$.

шебной сказки: есть, например, «спящая красавица» Настенька, обитательница интерната, находящаяся в коме, есть и злоумышленники, два молодых беспринципных санитара, которые Настеньку изнасиловали, есть и влюбленный в Настеньку отважный герой, ее «рыцарь-защитник» Глостер, который убивает преступников, есть и «всемогущий колдун» Бахатов, который помогает избавиться от мертвых тел. 26 В повести реализуется и мотив дома-клетки - замкнутого пространства (интернат), непременным атрибутом которого является тайна (вышеуказанное столкновение добра и зла) [Дворцова 2011, online]. В Ногтях носителями этой тайны являются, конечно, Глостер и Бахатов.

27 Как замечает литературовед Ольга Иоскевич, тема безумия: «(..) представлена во все литературные эпохи, особенно в те, которые проблематизируют отношения между литературой и действительностью (средневековье, барокко, романтизм, модернизм и постмодернизм)» [Иоскевич 2009, 8]. 
«Безумие» является предметом внимания, интенсивного обсуждения и исследования не только в медицинских трудах. Попытки объяснить феномен безумия (проникнуть в глубинный смысл этого феномена) и каким-то образом классифицировать душевнобольных предпринимаются также в пределах философского 28 , культурологического, антропологического, социологического дискурсов, но и одновременно в художественной литературе. Интерес к теме безумия как иррациональному, трудно постижимому явлению, к теме психических расстройств, к «странным» людям, по тем или другим признакам отличающимся от большинства, к «ущербным» и «нездоровым» личностям, прослеживается в творчестве многих писателей разных эпох. Уместно при этом отметить, что довольно сложно однозначно и точно определить, что скрывается за понятиями: «безумие» и «безумец». Как известно, под категорию «безумия» попадают самые разнородные явления. Итак, к ним относят и психические заболевания с соответствующей клинической симптоматикой ${ }^{29}$, и так называемые «странности» в поведении, состоянии, мировосприятии, мышлении, во взаимоотношениях с другими людьми, то есть отклонения от широко понимаемой общественной нормы, принятой в конкретном окружении, в конкретное время [Медведева, Казаков 2011, 33]. Конечно, следует здесь еще обратить внимание и на тот факт, что медики (как специалисты) и обычные люди (как дилетанты в области медицины) по-разному воспринимают безумие. Как подчеркивает, например, психолог и психотерапевт Александр Сосланд:

Я резко против разговоров о «ненормальности», определяемой исключительно по внешним признакам. Любой, пусть крайне вызывающе ведущий себя человек, должен считаться нормальным до тех пор, пока профессиональная экспертиза не констатирует наличия у него душевной болезни». Сосланд добавляет при этом: «(...) человек, отличающийся какими-то яркими внешними признаками, с заурядной, обывательской точки зрения скорее будет рассматриваться как ненормальный, в то время как огромное большинство душевнобольных одеваются вполне скромно и ничем особым не выделяются среди всех остальных. (...) Профессиональная точка зрения совершенно не совпадает с обывательской [Фурман 2015, online].

28 Необходимо уточнить, что имеются два основных подхода к анализу феномена безумия, понимаемого как психическое и душевное состояние, поведение, противоположное разумности. Это медицинский и философский подходы. С медицинской точки зрения безумие является болезнью (психическим заболеванием), согласно философскому подходу безумие - это духовная (моральная, религиозная) категория [Ивин 2004, online].

29 Это уже психическая патология, устойчивые расстройства личности, врожденная психическая болезнь. 
Несомненно, можно говорить об устойчивом, неугасающем интересе писателей к стихии безумия (к многоликости этого явления), которое всегда в равной мере пугало и притягивало, вызывая тем самым постоянное стремление познать его загадку или хотя бы приблизиться к раскрытию его тайны.

В елизаровской игре с безумием, в его представлении о безумцах в какой-то степени соединяются, переплетаются и взаимодополняют друг друга элементы, свойственные фольклорному образу наивного 30 Иванушки-дурачка ${ }^{31}$, составляющие романтической концепции «гениального безумца», а также прослеживаются некоторые следы двух, на первый взгляд, совершенно противоположных явлений, то есть юродства (здесь намечаются тенденции сакрализации безумия ${ }^{32}$ ) и бесноватости (бесноватый как безумец, одержимый бесами). Но как замечает литературовед Наталья Нагорная:

Юродивый, как и демон, - существо "промежутка", существующее на границе между мирами: рациональным, дневным, внешним и иррациональным, ночным, внутренним. (...) "Демон”, “бесноватый” и юродивый, несмотря на противоположные начала дьявольского и божественного, воплощенные в них, вносят одинаковый элемент страха в душу постороннего наблюдателя в силу своей “инакости”, отчужденности от привычного мира [Нагорная 1997, 74].

Своего рода противоядием от одиночества и от вышеуказанной «отчужденности от привычного мира» (но также от его агрессивной враждебности) становится для Глостера волшебный и восхитительный мир звуков. Однажды, совсем неожиданно для себя, Саша открывает невероятную красоту, скрывающуюся именно в звуках. Елизаровский

30 Хотя за этой наивностью и простодушием может скрываеться некое высшее, тайное, труднодостижимое, эзотерическое знание, умение проникнуть в метафизическую глубину жизни [Грицанов 2002, online]. Как полагал, в свою очередь, французский философ Мишель Фуко, в безумии существует проблеск «истины», который недоступен разуму [Половцев 2006, online].

31 В бытовых и волшебных сказках появляется дурак-мудрец, причем со временем намечаются резкие изменения в трактовке этого образа, и в результате «фольклорный дурак дает начало развитию образов плута, шута с их ложным непониманием, добродушного простака с его наивным непониманием, священного безумца с его героической жаждой переустройства мира по идеальному образцу и дурака-праведника, аккумулирующего в себе черты блаженного, юродивого» [Дикун 2010, 3, 4].

32 По мысли Дмитрия Лихачева, филолога и культуролога: «Юродивый - "мнимый безумец", самопроизвольный дурачок, скрывающий под личиной глупости святость и мудрость» [цит. по: Иоскевич 2009, 12]. 
герой начинает проявлять способности к музыке (раньше он с настоящей страстью занимался отвинчиванием неотвинчиваемого, то есть шариков от железных кроватей), черпая вдохновение, как ему кажется, из собственного горба ${ }^{33}$ :

(...) В тот день я себя неважно чувствовал, навалилась очередная хандра, и перекололи меня всякой дрянью. И тут заиграла музыка. (...) Я слушал не ушами, а мыслью, холодившей пустоту горба. Моя искривленная плоть чувствовала с музыкой родство, стремилась стать ее горбохранилищем. (...) Мои всегда сухие глаза свело судорогой слез, я зарыдал, и только оттого, что в моем мясистом музыкальном центре играл самостоятельный, неслышный миру органчик [Елизаров 2011, 16-17].

Затем, благодаря своему «доброму ангелу», декану Валентину Валерьевичу, Глостер заканчивает консерваторию, становится талантливым пианистом. Со временем он приобретает удивительную, магическую власть над инструментом, и выясняется, что эту власть ему дает ритуал с ногтями, совершаемый Бахатовым. Значит, снова наступает вторжение сверхъестественного в обыденную жизнь.

Благодаря русскому меценату (точнее, криминальному псевдомеценату) Тоболевскому ${ }^{34}$, в свою очередь, Саша начинает выступать, гастролировать.

«Случай Глостера и его уникального горба» можно рассматривать с чисто медицинской точки зрения и просто определить как тип шизофрении - раздвоение личности на себя и на гениального музыканта из горба. Но уместно здесь также упомянуть о своего рода «романтизации» безумия, когда речь идет о творческом безумии и особо одаренном безумце, то есть говорится о непосредственной связи помешательства и гениальности ${ }^{35}$. Как известно, для романтиков, например,

33 Но горб - это не только источник вдохновения, в нем сконцентрировалась и скорбь, и внутренняя злость, гнев, раздражение. Интересно, что в народной мудрости горб оценивался по-разному: одни считали, что это наказание, другим казалось, что это особая отметка Бога.

34 Поддерживая материально всякого рода «монстров», Тоболевский просто пытается заработать большие деньги - ведь сочетание внешней уродливости и необыкновенной одаренности (можно сказать, что и внутренней, душевной красоты) представляет собой желанный и дорогой товар: «У меня не вызывало сомнений, что подсознательная мечта Тоболевского - создать русский паноптикум, труппу монстров и уродов, пляшущих или пиликающих. Искусство как самоцель его мало интересовало» [Елизаров 2011, 58].

35 Предполагается при этом, что по сравнению с миром психически больного мир здорового человека намного беднее. Хотя мнения здесь разделяются: «Немалая часть великих людей убеждена в том, что есть внутренняя связь между гениальным твор- 
безумие нередко было признаком именно исключительности и гениальности человека ${ }^{36}$. В связи с этим оно воспринималось как положительное состояние, идентифицировалось с реализацией скрытых потенциалов человека, с творческим экстазом, а также с возможностью обретения полной свободы духа [Таврина 2013, 94, 95]. В эпоху романтизма культивировался идеал неординарной, талантливой, «внебытовой» личности, устремленной к духовным поискам и поэтому способной полностью оторваться от повседневной действительности, и тем самым приобщиться к высшим сферам бытия, недоступного обывательскому (обычному, рациональному) восприятию [Иоскевич 2009, 27]. В таком контексте безумие Саши можно считать метафорой выхода человека за рамки его естественных, человеческих возможностей, а это обозначает, что погружаясь в чудесное музыкальное пространство, елизаровский герой хотя бы на мгновение «прикасается» к высшей реальности, к миру подлинной гармонии и настоящей красоты ${ }^{37}$.

Загадочная смерть Бахатова ${ }^{38}$ - это не только разрыв мистической связи между выпускниками интерната для слабоумных детей, это и конец карьеры Саши, так как именно в эту минуту гениальный «внутренний музыкант» совсем внезапно и, как оказывается, навсегда «прекращает свою деятельность», прекрасные и неповторимые звуки, доходящие из горба, просто замолкают. Таким образом Елизаров показывает, что слава и удача, которые начали сопутствовать Глостеру в жизни, были лишь кратковременным и обманчивым сном, иллюзией когда-то поставленный диагноз «дурачка» отменить нельзя. Писатель отчетливо намекает, что теперь уже совсем беззащитный горбун, так как лишенный и «сверхъестественной» поддержки своего «ангела-хра-

чеством и психопатологическими расстройствами. Многие даже полагают, что патология способствует развитию таланта и даже стимулирует его. Оппоненты придерживаются такой точки зрения, что ничто гениальное не может вырасти на почве болезни, что гений - это высшее проявление здоровья, а не болезни» [Ткачук 2007, online].

36 «Этим объясняется обращение к "мифу о гениальном безумие", который с потерей рассудка утрачивает связь с миром обывателей и творит по законам ирреального бытия, недоступного филистерскому восприятию» [Таврина 2013, 94]. Творческое дарование (изобретательское, поэтическое, музыкальное) «гениального безумца» достигает своего апогея именно в период его сумасшествия.

37 См. также Pańkowska E., 2018, Михаил Елизаров: между постмодернизмом и «магическим реализмом» (Ногти, Библиотекарь, Мультики)..., с. 202.

38 На его шее Глостер увидел следы от собачьего укуса, а официальной причиной смерти был «приступ гипертоксической шизофрении». Значит, в очередной раз намечается здесь елизаровский интерес к двойным мотивировкам: ведь следы от укуса «дьявольской» собаки могут быть просто плодом больного воображения Глостера. 
нителя», и музыкальной одаренности, опять становится существом, никому не нужным, поэтому на своем жизненном пути он встречать будет только жестокость и непонимание со стороны окружающих. Подытоживая, можно сделать вывод, что Елизаров написал очень грустную «притчу» о торжестве бездушия и бездуховности, о торжестве цинизма и всеохватывающего человеческого равнодушия.

В анализируемом тексте найдем, конечно, литературные и исторические аллюзии. Например, Глостер сравнивает себя с итальянским скрипачом-виртуозом и композитором, Никколо Паганини (1782$1840)^{39}$, а также с вызывающим страх горбатым звонарем Квазимодо, героем романа Виктора Гюго Собор Парижской Богоматери (1831). В повести Елизарова просматриваются несомненные интертекстуальные связи с романом Саши Соколова Школа для дураков (1976), но в заключение мы предлагаем сопоставить Ногти с ранней повестью Виктора Пелевина Затворник и Шестипальй (1990). Герои пелевинского произведения - это два цыпленка, два куриных уродца: Затворник с философским складом ума (своего рода наставник) и Шестипалый с отклонениями в физическом развитии. Цыплята учатся летать, чтобы вырваться из убогого существования инкубатора и обрести истинный смысл жизни - обрести свободу. Затворнику и Шестипалому действительно удается улететь и покинуть единственный известный им до сих пор мир Бройлерного комбината, мир полной несвободы. Может быть, что они приобретают лишь призрачную свободу, но все-таки пелевинские «странные» цыплята вдали видят какой-то отблеск света ${ }^{40}$. Елизаровским «уродцам» тоже удается вырваться из замкнутого пространства интерната, но это ничего не меняет, так как их постоянно и везде окружает только мрак, зловещая темнота, а вдали они видят лишь «силуэт» неумолимо надвигающейся смерти, к которой они при-

39 В связи с елизаровским горбуном-гением интересными являются следующие факты: «Известность ему (Паганини - Е.Р.) принесли его необычный вид и поведение во время концертов. (...) Он держал себя подчёркнуто загадочно и вначале не пресекал распространение о себе самых фантастических слухов. (...) Известно, что Паганини страдал синдромом Марфана, редким генетическим заболеванием, характерными особенностями которого являются сколиоз, патологически длинные конечности, подвижность суставов, проблемы со зрением и патология аорты. Некоторые ученые предполагают связь этого синдрома с гениальностью, поскольку он встречается у многих гениев. Скорей всего, именно заболевание и придавало Паганини своеобразную внешность («горбун с кошачьим глазом»), а также порождало слухи о его связях с нечистой силой» [Денисова 2014, online].

40 См. подробнее Паньковска Э., 2006, Мотив поисков свободы в творчестве Виктора Пелевина, "Studia Wschodniosłowiańskie" т. 6, с. 87-89. 
выкли с детства ${ }^{41}$. С самого начала герои были обречены на скорую гибель, и они жили как будто только в ожидании этого неизбежного конца, поэтому заканчивая рассказ о себе и о своем верном и единственном друге Бахатове, Глостер с невозмутимым спокойствием констатирует: «Я шел к машине без надежды и без страха. Смерть откладывалась лишь до того момента, пока трупный яд Бахатова (...) полностью не перельется в мое тело и не остановит сердце» [Елизаров 2011, 79].

Как справедливо замечает Роман Богословский: «Повесть «Ногти» Михаила Елизарова увидела свет в 2001 году. И этот выстрел из ружья новейшей русской литературы был столь оглушителен, что его эхо до сих пор носится по стране» [Богословский 2019, online]. Это произведение, несомненно, производит на читателя тягостное впечатление, но и застваляет всерьез задуматься о судьбе ущербных существ, беспомощных и беззащитных, часто отверженных и семьей, и обществом. Повесть Ногти, как и другие тексты Елизарова, оставляет читателя со множеством вопросов и возможностей интерпретации. Присутствующий в повести «черный мистицизм» придает ей оттенок завораживающей, но и ужасающей таинственности.

\section{Литература}

Basinskij P.V., 2012, Mihail Elizarov. «My vyšli pokurit' na 17 let...». Sbornik rasskazov. - M.: Astrel', 2012, "Rossijskaâ gazeta" nr 248 (5921). [Басинский П.В., 2012, Михаил Елизаров. «Мь вылили покурить на 17 лет...». Сборник рассказов. - М.: Астрель, 2012, «Российская газета» № 248 (5921)], [online], https://rg.ru/2012/10/26/rasskazi.html, [08.02.2020].

Bavil'skij D.V., 2010, Mihail Elizarov: «Čto-to vrode trudovoj terapii...». Laureat Bukera kommentiruet vyhod svoego novogo romana «Mul'tiki». Interv' $\hat{u}$, "Častnyj korrespondent", ot 24 iûlâ. [Бавильский Д.В., 2010, Мuхаил Елизаров: «Что-то вроде трудовой терапии...». Лауреат Букера комментирует вьход своего нового романа «Мультики». Интервью, «Частный корреспондент», от 24 июля], [online], http://www.chaskor.ru/article/ mihail_elizarov_chto-to_vrode_trudovoj_terapii_18727, [08.02.2020].

Besedin P., 2012, Mihail Elizarov: «Rossiâa slovocentričnâ̂ strana». Interv' $\hat{u}$. [Беседин П., 2012, Михаил Елизаров: «Россия словочентричная страна». Интервью], [online], http://blog.thankyou.ru/mihail-elizarov-rossiya-slovo tsentrichnaya-strana/, [08.02.2020].

41 В интернате смерть была обыденностью: «Они (жители интерната - Е.Р.) умирали тихо и незаметно: кто во сне, кто в момент кормления (...). Всегда умирали по двое, с небольшим интервалом. Каждому находился братик или сестричка в смерти. Если родные не приезжали за трупами, их хоронили на собственном кладбище, находившемся на территории интерната» [Елизаров 2011, 13]. 
Bezrukavaâ M.V., 2014, Struktura povestvovaniâ $i$ sîžetnyj mir v romanah M. Elizarova, "Vektor nauki TGU" nr 3 (29), s. 99-103. [Безрукавая M.В., 2014, Структура повествования и сюжетньй мир в романах М. Елизарова, «Вектор науки ТГУ» № 3 (29), с. 99-103.]

Bogoslovskij R., 2019, Iz sovetskoj preispodnej: povest' o russkom koldovstve. [Богословский Р., 2019, Из советской преисподней: повесть о русском колдовстве], [online], https://regnum.ru/news/cultura/2651536.html, [08.02.2020].

Burmistrova Û., 2008, Mihail Elizarov: «Russkij pisatel' - inostranec v Rossii...».

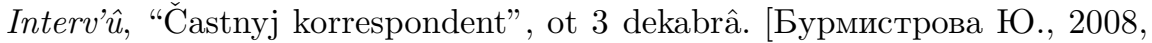
Михаил Елизаров: «Русский писатель - иностранеи в России..». Интервью, «Частный корреспондент», от 3 декабря], [online], http://www. chaskor.ru/article/mihail_elizarov_russkij_pisatel_-_inostranets_v_rossii_1564, [08.02.2020].

Dajs E., 2012, Bibliotekar' iz Nag-Hammadi. [Дайс E., 2012, Библиотекарь из Hаг-Хаммади], [online], http://russ.ru/pole/Bibliotekar-iz-Nag-Hammadi, [08.02.2020].

Dement'eva E., 2014, Pisatel’ Mihail Elizarov: «Evropa stavit na Ukraine opasnyj èksperiment». Interv'û. [Дементьева Е., 2014, Писатель Михаил Елизаров: «Европа ставит на Украине опасный эксперимент». Интервью], [online], https://spb.mk.ru/articles/2014/08/28/pisatel-mikhail-elizarov-ev ropa-stavit-na-ukraine-opasnyy-eksperiment.html, [08.02.2020].

Denisova T., 2014, Nikkolo Paganini: Skripač D'âvola. [Денисова T., 2014, Никколо Паганини: Скрипач Дьявола], [online], http://parnasse.ru/prose/essay/ publicism/nikolo-paganini-skripach-djavola.html, [08.02.2020].

Dikun E.S., 2010, «Strannye» geroi v russkoj literature, "Naukovi zapiski Harkivs'kogo nacional'nogo pedagogičnogo universitetu im. G.S. Skovorodi" vip. 1.2, s. 3-17. [Дикун Е.С., 2010, «Страннье» герои в русской лиmературе, «Наукові записки Харківського національного педагогічного університету ім. Г.С. Сковороди», вип. 1.2, с. 3-17.]

Drozdova N., 2017, «Otkrovenno ne hvataet lûdâm Stalina»: v Peterburge vystupil Mihail Elizarov. [Дроздова Н., 2017, «Откровенно не хватает людям Сталина»: в Петербурге выступил Михаил Елизаров], [online], https:// nevnov.ru/496287-otkrovenno-ne-hvataet-lyudyam-stalina-v-peterburge-vy stupil-mihail-elizarov, [08.02.2020].

Dvorcova N., 2011, Metafizika knigi i čteniâ v literaturnom soznanii 2000-h gg., [v:] XXI vek. Itogi literaturnogo desâtiletiâ: Âzyk - Kul'tura - Obŝestvo. Materialy meždunarodnoj naučno-praktičeskoj konferencii, 21 aprelâ - dekabr' 2010 goda, pod red. A.Û. Bol'šakovoj i A.A. Dyrdina, Ul'ânovsk. [Дворцова Н., 2011, Метафизика книги и чтения в литературном сознании 2000-х г2., [в:] ХХІ век. Итоги литературного десятилетия: Язык Культура - Общество. Материалы международной научно-практической конференции, 21 апреля - декабрь 2010 года, под ред. А.Ю. Большаковой и А.А. Дырдина, Ульяновск], [online], http://www.rospisatel.ru/ konferenzija/dvorzova.htm, [08.02.2020]. 
Elizarov M.Û., 2011, Nogti, Moskva. [Елизаров М.Ю., 2011, Ногтu, Москва.]

Filosofîa: ènciklopedičeskij slovar', 2004, pod red. Ivina A.A., Moskva. [Философия: энииклопедический словарь, 2004, под ред. Ивина А.А., Москва.]

Furman I., 2015, «My nikogo ne nazyvaem nenormal'nym. Takogo diagnoza net»: Aleksandr Sosland o psihičeskom zdorov'e. Interv'û. [Фурман И., 2015, «Мbl никого не называем ненормальныл. Такого диагноза нет»: Александр Сосланд о психическом здоровье. Интервью], [online], https://theoryand practice.ru/posts/11759-sosland, [08.02.2020].

Globa P.P., D'âvol'skie mety $i$ božestvennye znaki. [Глоба П.П., Дьявольские метыл и божественные знаки], [online], http://www.kiberstar.ru/stars/znaki_ body.htm, [08.02.2020].

Imihelova S.S., Kolmakova O.A., 2016, Sovremennâ̂a russkâ̂ proza, Ulan-Udè. [Имихелова С.С., Колмакова О.А., 2016, Современная русская проза, Улан-Удэ.]

Ioskevič O.A., 2009, Na puti $k$ «bezumnomu» narrativu (bezumie v russkoj proze pervoj poloviny XIX v.), Grodno. [Иоскевич О.А., 2009, На путu $\kappa$ «безумному» нарративу (безумие в русской прозе первой половинь $X I X$ в.), Гродно.]

Istoriâ filosofii. Ènciklopediâ, 2002, sost. i glav. nauč. red. Gricanov A.A., Minsk. [История философии. Энииклопедия, 2002, сост. и глав. науч. ред. Грицанов А.А., Минск], [online], https://www.logic-books.info/sites/default/ files/gricanov_red._istoriya_filosofii._enciklopediya.pdf, [08.02.2020].

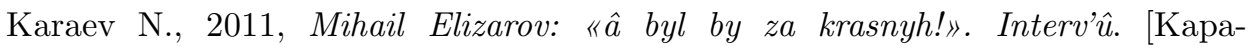
ев Н., 2011, Михаил Елизаров: «я был бы за красньх!». Интервью], [оnline], https://rus.postimees.ee/409646/mihail-elizarov-ya-byl-by-za-krasnyh, [08.02.2020].

Kislicyn K.N., 2011, Magičeskij realizm, "Znanie. Ponimanie. Umenie" nr 1, s. 274-277. [Кислицын К.Н., 2011, Магический реализм, «Знание. Понимание. Умение» № 1, с. 274-277.]

Kolmakova O.A., 2015, Poètika metamorfozy v proze M. Elizarova, "Vestnik TOGU" nr 1 (36), s. 223-232. [Колмакова О.А., 2015, Поэтика метаморфозы в прозе М. Елизарова, «Вестник ТОГУ» № 1 (36), с. 223-232.]

Marhinina M., 2013, Mihail Elizarov: «ÂA ne pytaûs' manipulirovat' soznaniem čitatelâ». Interv' $\hat{u}$, "Vestnik Surgutskogo rajona" nr 40, ot 4 oktâbrâ. [Mapхинина М., 2013, Михаил Елизаров: «Я не пытаюсь манипулировать сознанием читателя». Интервью, «Вестник Сургутского района» № 40, от 4 октября], [online], http://vestniksr.ru/news/6161-mihail-elizarov-ja-nepytayus-manipulirovat-soznaniem-chitatelja.html, [08.02.2020].

Medvedeva D.A., Kazakov A.A., 2011, Problema bezumiâ v romanah F.M. Dostoevskogo 1865-1880-h gg., "Vestnik Tomskogo gosudarstvennogo universiteta" nr 351, s. 33-38. [Медведева Д.А., Казаков А.А., 2011, Проблема безумия в романах Ф.М. Достоевского 1865-1880-x г2., «Вестник Томского государственного университета» № 351, с. 33-38.] 
Mihail Elizarov - Portrety, 2010. [Mихаил Елизаров - Портреть, 2010], [online], http://www.sobaka.ru/city/portrety/4568, [08.02.2020].

Nagornaâ N.A., 1997, Fenomen ûrodstva i ûrodivyj geroj A.M. Remizova, "Kul'tura i tekst" nr 1, s. 73-75. [Нагорная Н.A., 1997, Феномен юродства и юродивый герой А.М. Ремизова, «Культура и текст» № 1, с. 73-75.]

Ohotin G., 2008, Buker iz bunkera. [Охотин Г., 2008, Букер из бункера], [online], http://os.colta.ru/literature/events/details/6471/, [08.02.2020].

Pavlov S., 2018, Elizarov: «literatura v XXI veke - èto sfera uslug». Interv'û. [Павлов С., 2018, Елизаров: «литература в ХХІ веке - это сфера услуг». Интервъю], [online], https://podled.media/elizarov/, [08.02.2020].

Polovcev D.O., 2006, Inakovost' kak filosofsko-literaturnâa kategoriâ. [Половцев Д.О., 2006, Инаковость как философско-литературная категория], [online], https://core.ac.uk/reader/38536933, [08.02.2020].

Prilepin Z., 2015, «Âvlenie liberalizma v russkoj politike - bezuslovno vrednoe $i$ opasnoe». Interv'û s Mihailom Elizarovym, "Literaturnaâ Rossiâ" nr 2008/13. [Прилепин 3., 2015, «Явление либерализма в русской политике - безусловно вредное и опасное». Интервью с Михаилом Елизаровым, "Литературная Россия" № 2008/13], [online], https://itrossia.ru/item/2621yavlenie-liberazizma-v-russkoj-politike-bezuslovno-vrednoe-i-opasnoe-s-mik hailom-elizarovym-beseduet-zakhar-prilepin/, [08.02.2020].

Safrošina O., 2012, Mihail Elizarov: roman s pesnej. [Сафрошина O., 2012, Михаил Елизаров: роман с песней], [online], https://www.erarta.com/ru/ museum/news/report/detail/news-00172/, [08.02.2020].

Smirnov A., 2008, Mihail Elizarov: «Bardak ostanovlen». Interv' $\hat{u}$, "Zavtra" nr 50 (785), ot 9 dekabrâ. [Смирнов А., 2008, Михаил Елизаров: «Бардак остановлен». Интервью, "Завтра" № 50 (785), от 9 декабря], [online], https://public.wikireading.ru/177188, [08.02.2020].

Smirnov A., 2012, Šanson'e iz htoni. Interv'û, "Zavtra" nr 9 (953), ot 29 fevralâ. [Смирнов А., 2012, Шансонье из хтони. Интервью, "Завтра" № 9 (953), от 29 февраля], [online], http://zavtra.ru/blogs/shansone-iz-htoni, [08.02.2020].

Šapoval S., 2008, Mihail Elizarov: «ÂA čaû spravedlivosti, no ne znâu, čto èto takoe». Interv'û s Mihailom Elizarovym, "Kul'tura" nr 48 (7661). [Шаповал C., 2008, Михаил Елизаров: «Я чаю справедливости, но не знаю, что это такое». Интервью с Михаилом Елизаровьм, "Культура" № 48 (7661)], [online], http://www.litkarta.ru/dossier/elizarov-kultura/dossier_21995/, [08.02.2020].

Tarnowska I., 2013, Uŝerbnye i nenormal'nye ličnosti. [Tarnowska I., 2013, Ущербнье и ненормальные личности], [online], https://irena-tarno.livejournal. com/64571.html, [08.02.2020].

Tavrina A.M., 2013, Obraz geroâ-bezumca v russkoj romantičeskoj povesti 30-40-h godov XIX veka, "Vestnik Čerepoveckogo gosudarstvennogo universiteta" t. 1, nr 1, s. 92-96. [Таврина А.М., 2013, Образ героя-безумиа в русской романтической повести 30-40-х годов ХІХ века, "Вестник Череповецкого государственного университета" т. 1, № 1, с. 92-96.] 
Tkačuk T., 2007, Kak vosprinimaetsâ obydennym soznaniem bezumie. [Ткачук T., 2007, Как воспринимается обьценным сознанием безумие], [online], https://www.svoboda.org/a/416348.html, [08.02.2020].

Tokarev A., 2008, Hranitel' rodiny. O tvorčestve Mihaila Elizarova. [Токарев A., 2008, Хранитель родиньь. О творчестве Михаила Елизарова], [оnline], https://www.litres.ru/aleksandr-tokarev-16161973/iskusstvo-pravdy /chitat-onlayn/page-3/, [08.02.2020].

Ûr'ev D.Û., 2016, Proza Mihaila Elizarova (poètika i nravstvennaâ problematika). Avtoreferat dissertacii na soiskanie učenoj stepeni kandidata filologičeskih nauk, Krasnodar. [Юрьев Д.Ю., 2016, Проза Михаила Елизарова (поэтика и нравственная проблематика). Автореферат диссертации на соискание ученой степени кандидата филологических наук, Краснодар], [online], https://dlib.rsl.ru/01006651511, [08.02.2020].

Zaharova E., 2016, Mihail Elizarov v Tambove: «U menâ voinskie pesni. Pesni voobŝe dolžny byt' voinskimi». Interv'û. [Захарова Е., 2016, Михаил Елизаров в Тамбове: «У меня воинские песни. Песни вообще должны быть воинскими». Интервьюо, [online], https://tmb.news/exclusive/intervyu/mikhail _elizarov_v_tambove_u_menya_voinskie_pesni_pesni_voobshche_dolzhny_byt_ voinskimi_/, [08.02.2020].

\section{IN "THE DARK” AND "MYSTERIOUS" WORLD OF MIKHAIL ELIZAROV'S LITERARY WORKS (MADNESS AND "BLACK MAGIC" IN THE STORY FINGERNAILS)}

\section{ABSTRACT}

Key words: Mikhail Elizarov, abnormality, madness, mystical, magical

Mikhail Elizarov (born 1973 in Ukraine) undoubtedly belongs to the most "bizarre" and controversial contemporary Russian writers (more precisely, he is a Russian and Ukrainian writer). Elizarov is also known as a musician and a songwriter. He is the winner of literary award The Russian Booker Prize (in 2008) for his novel The Librarian (this novel was called one of the most controversial prize-winning novels). Elizarov's literary works "balance" on the verge of postmodernist and realistic practice; the writer is known for scandalous but intellectual high-energy prose (sometimes he is compared to Nikolai Gogol, sometimes - to Vladimir Sorokin). The purpose of this article is to show and discuss distinguishing features of Elizarov's prose, to identify central motifs and themes in his selected literary works. The story Fingernails is analyzed in this paper. Special attention is paid to Elizarov's conception of madness and abnormality, and also to his point of view on relationship between "normal" and "abnormal" (strange, different from what is usual or expected). 